\title{
Oddziaływanie pandemii COVID-19 na finanse jednostek samorządu terytorialnego
}

\section{Impact of the COVID-19 pandemic on finances of the local government units}

Streszczenie. Recesja spowodowana pandemią COVID-19 oraz wprowadzonym lockdownem była ważnym czynnikiem oddziałującym na stan finansów samorządu terytorialnego w latach 2020-2021. Pandemia wymusiła konieczność dynamicznych zmian i dostosowania się jednostek samorządu terytorialnego do nowej rzeczywistości. W artykule podjęto próbę oceny wpływu pandemii COVID-19 na sposób wydatkowania środków publicznych przez jednostki samorządu terytorialnego. Zaprezentowano szanse i zagrożenia wywołane pandemią COVID-19 na funkcjonowanie jednostek samorządu terytorialnego podyktowane zmieniającym się ustawodawstwem w zakresie dochodów i wydatków, na szczeblu gmin, powiatów i województw.

Słowa kluczowe: pandemia COVID-19; lockdown; finanse samorządu terytorialnego; dochody; wydatki. 


\begin{abstract}
The recession caused by the COVID-19 pandemic and an introduced lockdown has been an important factor affecting the financial condition of local government in 2020-2021. The pandemic forced the need to dynamically change and adapt local government units to the new reality. The article attempts to assess an impact of the COVID-19 pandemic on a way public funds are spent by local government units. The paper presents opportunities and threats in the scope of the impact of the COVID-19 pandemic on functioning of local government units dictated by the changing legislation in the field of income and expenditure at the level of communes, districts and voivodships.
\end{abstract}

Keywords: COVID-19 pandemic; lockdown; finance of local government units; income; expenses.

\title{
1. Wprowadzenie
}

Finanse jednostek samorządu terytorialnego ${ }^{1}$ odgrywają ważną rolę w sposobie gospodarowania środkami publicznymi. Na poziomie gmin, powiatów oraz województw realizowane są zadania publiczne, które wpływają na jakość życia społeczności lokalnej, model realizowania zadań z zakresu edukacji, kultury, dostępu do usług publicznych, infrastruktury oraz możliwości finansowania inwestycji i projektów. Aktywność na szczeblu samorządowym rzutuje na stan gospodarki kraju. W związku z powyższym na poziomie j.s.t. pojawił się problem obciążenia zadaniami, które nie zawsze są adekwatne do uzyskiwanego finansowania. Nieoczekiwany wybuch pandemii COVID-19 wpłynął na spadek nadwyżki operacyjnej w j.s.t., pozwalającej na realizację inicjatyw rozwojowych, podejmowanie działań o charakterze interwencyjnym w przypadku wystąpienia kryzysów. Z tego względu ważne jest współdziałanie pomiędzy rządem a władzami samorządowymi, które pozwala na wzmocnienie stabilności finansowej j.s.t.

Przedmiot opracowania stanowi próba dokonania oceny wpływu pandemii COVID-19 na sposób wydatkowania środków publicznych przez jednostki samorządu terytorialnego.

\footnotetext{
${ }^{1}$ Dalej: j.s.t.
} 
Opracowanie przygotowane zostało w oparciu o obowiązujące regulacje prawne oraz wybrane pozycje literatury przedmiotu. Podsumowanie stanowią wnioski de lege lata oraz postulaty de lege ferenda. W celu zrealizowania tematyki artykułu wykorzystano metodę analizy formalno-dogmatycznej, teoretyczno-prawnej.

\section{Zmiany regulacji prawnych w czasie pandemii COVID-19 w zakresie finansów jednostek samorządu terytorialnego}

Ustawy, które zostały przyjęte w związku z rozwojem pandemii, wywarły wpływ na finanse jednostek samorządu terytorialnego. Regulacje te można pogrupować w następujący sposób.

Przepisy określające zasady wprowadzenia lockdownu - wprawdzie ich treść nie była wprost skierowana do jednostek samorządu terytorialnego, jednak oddziaływała ona na aktywność i decyzje podejmowane na poziomie samorządowym. Przepisy te dotyczyły zasad, limitów wprowadzonych w transporcie publicznym, obiektach użyteczności publicznej czy decyzji o przejściu na naukę zdalną. W związku ze wskazanymi ograniczeniami można było zauważyć wpływ na stan finansów j.s.t. poprzez wprowadzenie ram dla funkcjonowania działalności gospodarczej, skutkujący zmniejszeniem wpływów z podatków².

Przepisy ustanawiające obowiązki j.s.t. w zakresie przeciwdziałania pandemii, których efekty finansowe są trudne do zmierzenia, ponieważ w klasyfikacji budżetowej j.s.t. brak podziałek wskazujących na daną grupę wydatków pozostającą w bezpośrednim związkiem z COVID-19, o co postulowały władzy samorządowe.

Regulacje kierowane do gmin, powiatów, województw, mające na celu poprawę funkcjonowania jednostek w czasie pandemii. Ich wpływ nie wywiera wprost skutków o charakterze finansowym. Ta grupa przepi-

\footnotetext{
2 A. Nelicki, Wpływ ustawodawstwa okresu pandemii COVID-19 na finanse jednostek samorzqdu terytorialnego, Warszawa 2020, Fundacja im. Stefana Batorego, https://www.batory.org.pl/wp-content/uploads/2020/11/Wpływ-ustawodawstwaokresu-pandemii-COVID-19-na-finanse-JST.pdf, (dostęp: 10.11.2021 r.).
} 
sów obejmuje regulacje z obszaru równoważenia budżetu operacyjnego oraz zaciągania zobowiązań. Efekt oddziaływania na dochody j.s.t. wywarło zwiększenie możliwości udzielania przez j.s.t. zwolnień oraz ulg w podatkach i opłatach. Jako przykład tej kategorii regulacji należy wskazać użycie dochodów pochodzących z opłat za zezwolenie na handel alkoholem do finansowania działań mających na celu przeciwdziałanie pandemii i jej skutkom. Nowelizacja specustawy z 19 czerwca zniosła do końca 2020 roku autonomię części budżetu, dopuszczając wydawanie środków pochodzących z opłat za zezwolenia na handel alkoholem także na „działania związane z zapobieganiem, przeciwdziałaniem i zwalczaniem COVID-19 oraz wywołanych nim sytuacji kryzysowych” (zamiast jak to było wcześniej na cele związane z profilaktyką i rozwiązywaniem problemów alkoholowych oraz integrację społeczną osób uzależnionych od alkoholu). To rozwiązanie należy oceniać pozytywnie, ponieważ liczne początkowe ograniczenia wprowadzane w związku z pandemią skutecznie uniemożliwiały podejmowanie działań związanych z profilaktyką i rozwiązywaniem problemów alkoholowych.

Ustawodawstwo wydawane w celu przeciwdziałania pandemii COVID-19 i jej skutkom, w tym rezultatów wprowadzonych na jego podstawie restrykcji, w szczególności tzw. lockdownu ma początek w ustawie z dnia 2 marca 2020 r. o szczególnych rozwiązaniach związanych z zapobieganiem, przeciwdziałaniem i zwalczaniem COVID-19 ${ }^{3}$, innych chorób zakaźnych oraz wywołanych nimi sytuacji kryzysowych wywarło zarówno pośredni, jak i bezpośredni wpływ na funkcjonowanie jednostek samorządu terytorialnego. Ustawa ta w ciągu roku była ponad czterdziestokrotnie zmieniana, powodując wydanie w 2020 roku. piętnastu ustaw oraz około dwustu uchwał i rozporządzeń obejmujących problematykę dotycząca COVID-19. Ważnymi regulacjami była: ustawa z dnia 31 marca 2020 roku o zmianie ustawy o szczególnych rozwiązaniach związanych z zapobieganiem, przeciwdziałaniem i zwalczaniem COVID-19, innych chorób zakaźnych oraz wywołanych nimi sytuacji kryzysowych oraz nie-

\footnotetext{
3 Tekst jedn. Dz.U. z 2020 poz. 1842 ze zm.
} 
których innych ustaw ${ }^{4}$ oraz ustawa z dnia 19 czerwca 2020 roku o dopłatach do oprocentowania kredytów bankowych udzielanych przedsiębiorcom dotkniętym skutkami COVID-19 oraz o uproszczonym postępowaniu o zatwierdzenie układu w związku z wystąpieniem COVID-19 ${ }^{5}$. Ustawa ta zawiera przepisy nowelizujące specustawę z 2 marca tego roku (a także nowelizację specustawy z 31 marca), w tym zespół artykułów dotyczących funkcjonowania j.s.t., nazywanych „tarczą samorządową”.

Odrębną podgrupę stanowią przepisy dotyczące środków finansowych pozostających w dyspozycji j.s.t. Wśród przykładów można wymienić odroczenie opłat za dzierżawę wieczystą i opłat przekształceniowych, zwiększenie z 25\% do 50\% części wpływów z administrowania nieruchomościami Skarbu Państwa. Ważnym krokiem w zakresie oddziaływania na finanse samorządu było utworzenie Funduszu Inicjatyw Lokalnych o zapowiadanej łącznej wysokości ponad 12 mld $\mathrm{zł}^{6}$, dzięki któremu j.s.t. zyskały możliwość pozyskania środków inwestycyjnych z Funduszu Środków Przeciwdziałania COVID-19. Środki rozdysponowano na dotacje dla gmin, powiatów i miast, które wykazały trudności finansowe w związku z pandemią. Fundusze mogły zostać wykorzystane na inwestycje służące społecznościom lokalnym, m.in.: modernizacje i remonty szkół, przedszkoli, inwestycje w wodociągi i kanalizację, budowę żłobków, dróg, a także inne niezbędne lokalnie działania.

W ramach działań podejmowanych na poziomie j.s.t. mających za zadanie przyczynić się do rozluźnienia reguł fiskalnych oraz uzyskania wpływów do budżetu wprowadzono możliwość przekazania w 2020 roku rat części oświatowej, wyrównawczej, równoważącej i regionalnej subwencji ogólnej w terminach wcześniejszych oraz przesunięto termin wpłat do budżetu państwa dokonywanych przez j.s.t., których dochody podatkowe przekraczają ustawowy wskaźnik na II półrocze 2020 roku. W celu wzmocnienia bezpieczeństwa finansowego j.s.t. w roku 2020 wprowadzo-

\footnotetext{
Dz.U. z 2021 poz. 1192 ze zm., dalej: nowelizacja specustawy z 31 marca.

Tekst jedn. Dz.U. 2021 poz. 1072 ze zm.

Fundusz utworzony został uchwałą Rady Ministrów nr 102 z dnia 24 lipca 2020 r. w sprawie wsparcia na realizację zadań inwestycyjnych przez jednostki samorządu terytorialnego, podjętą na podstawie art. 65 ust. 28 nowelizacji specustawy z 31 marca (M.P. z 2020 r. poz. 662).
} 
ny został jednorocznego limitu długu na poziomie 80\% dochodów danej jednostki.

\section{Oddziaływanie lockdownu na stan finansów jednostek samorządu terytorialnego}

Podejmując próbę ogólnej analizy stanu finansów j.s.t., można stwierdzić, że od połowy 2020 roku dochodu j.s.t. wzrosły w odniesieniu do roku poprzedniego w mniejszym stopniu, niż zakładano. Pozytywnie należy ocenić jednoczesny niższy niż planowany wzrost wydatków bieżących, co wywołało jedynie niewielkie pogorszenie bilansu dochodów i wydatków, bez wpływu, który mógłby wywołać destabilizację płynności finansowej samorządów. Odnotowany wzrost dochodów majątkowych nie wyrównuje spadku nadwyżek operacyjnych, bowiem cechą charakteryzującą wydatki inwestycyjne jest to, że realizowane są one co do zasady pod koniec roku.

Struktura dochodów w j.s.t. jest złożona, pomimo obowiązywania zasady jedności budżetu, która oznacza, że pod względem prawnym dochody ze wszystkich źródeł służą do finansowania wydatków z wszystkich tytułów. Jednak od wskazanej zasady występują wyjątki dotyczące przede wszystkim dotacji. Należy wskazać, że analiza sytuacji dochodowej j.s.t. wymaga uwzględnienia zróżnicowania źródeł dochodów, gdyż nie zawsze wzrost dochodów z jednego źródła może kompensować ubytek dochodów z innego.

W zakresie wydatków j.s.t. trudno w jednoznaczny sposób wskazać zależność między wzrostem wydatków w niektórych dziedzinach mających na celu przeciwdziałanie pandemii i jej skutkom. Bez wprowadzenia podziałek klasyfikacji budżetowej pozwalających na oznaczenie określonych kategorii wydatków nie jest możliwe jednoznaczne wskazanie wartości wydatków bezpośrednio związanych z przeciwdziałaniem pandemii COVID-19. Podwyższone wydatki można było zaobserwować między innymi w zakresie środków przeznaczanych na oświatę, transport lokalny 
czy administrację publiczną. W znaczny sposób zmniejszyły się wydatki na kulturę, sport, organizację imprez publicznych. Na podstawie sprawozdań z wykonania budżetów j.s.t. nie jest możliwe jednoznaczne wskazanie wysokości oszczędności poczynionych dzięki temu przez samorządy.

Zestawienie dochodów i wydatków bieżących w pierwszych półroczach lat 2021, 2020 i 2019 prowadzi do konkluzji, że gorsza sytuacja finansowa j.s.t., po wyeliminowaniu podstawowych czynników wzrostu dochodów i wydatków niezwiązanych z pandemią, wywołana jest zarówno przez czynniki o charakterze dochodowym, jak i przez te o charakterze wydatkowym.

Ważnym źródłem dochodów j.s.t. są wpływy z podatków dochodowych na poziomie gmin i powiatów z podatku dochodowego od osób fizycznych, na szczeblu województw z podatku dochodowego od osób prawnych. W gminach dochody podatkowe obejmują także podatki i opłaty lokalne. Wpływ ustaw związanych z COVID-19 spowodował zmniejszenie wpływów z podatku dochodowego od osób fizycznych, podatku dochodowego od osób prawnych, a także podatku od czynności cywilnoprawnych $^{7}$. Początek pandemii i związane z nim ograniczenia w działaniu instytucji i urzędów wywołały spadek wpływów z opłaty skarbowej. Natomiast w zakresie podatków majątkowych oraz podatku od środków transportowych spadek wpływów był wynikiem decyzji j.s.t. o udzieleniu zwolnień, ulg i odroczeń udzielonych częściowo na podstawie obowiązujących przepisów zwykłych oraz specustaw „okołocovidowych”.

Jak wynika z powyższego, zmiany we wpływach podatkowych w zakresie podatku dochodowego od osób fizycznych, podatku dochodowego od osób prawnych oraz podatku od nieruchomości są odmienne w każdej j.s.t. co do każdego z tych źródeł. W przypadku podatków dochodowych bezpośrednią przyczyną spadku dochodów jest recesja spowodowana wprowadzonym w wyniku pandemii lockdownem. Natomiast w przypadku podatku od nieruchomości stopień niezrealizowania planów wynika

7 M. Gołaszewski, Finanse samorzq̨dowe jeszcze bardziej zagrożone, „Wspólnota” 2020, nr 4, s. 22-23. 
z działań samych j.s.t. z udzielanych ulgi zwolnień ${ }^{8}$. Należne j.s.t. wpływy z podatku dochodowego od osób prawnych trafiają do budżetu j.s.t. zależnie od wpływów podatników, którzy prowadzą działalność gospodarczą na terenie danej jednostki, natomiast przy podatku dochodowym od osób fizycznych $^{9}$ zależnie od udziału w bieżących wpływach podatkowych od tego, jaką część łącznej kwoty podatku należnego od wszystkich podatników w kraju stanowił podatek należny za rok wcześniejszy o dwa lata od podatników będących mieszkańcami danej jednostki. W rezultacie spadek dochodów przy podatku dochodowym od osób fizycznych jest podobny procentowo dla wszystkich jednostek - jednak nie w odniesieniu do dochodów z lat poprzednich, a uwzględniając kwoty prognozowane z przekazanych przez Ministerstwo Finansów informacjach, stanowiących podstawy planów finansowych dla j.s.t.

Oddziaływanie pandemii COVID-19 można analizować na płaszczyźnie wpływu gospodarczego. W kontekście spadku dochodów z podatku dochodowego od osób prawnych, powołując się na treść wyników badań przeprowadzonych przez dr hab. Jacka Wantocha-Rekowskiego, prof. UMK oraz dr Małgorzatę Cilak obrazujących skutki pandemii w latach 2020-2021, należy uwzględnić fakt, że dane wykorzystane w badaniach w roku 2021 stanowią jedynie prognozy dokonywane w trakcie trwające pandemii przy zmiennym jej nasileniu. Analizując wpływy z podatku dochodowego od osób prawnych, autorzy badania wskazali, że dochód ten, mimo jego znaczącej roli w zasileniu finansowym województw, nie jest stabilny. Rosnące w czasie pandemii wydatki j.s.t. powodują stan niepewności finansowej, negatywnie oddziałującej na działalność samorządów, które w przypadku podatków dochodowy nie są wyposażone $\mathrm{w}$ instrumenty prawne pozwalające na zwiększenie efektywności. W tym kontekście autorzy wskazali na ważny postulat zmian prawodawczych, które pozwoliłyby na uzupełnienie niedoborów wpływów

8 K. Kostyk-Siekierska, Wpływ pandemii COVID-19 na sytuację finansowq i funkcjonowanie jednostek samorzq̨u terytorialnego, „Zeszyty Naukowe Małopolskiej Wyższej Szkoły Ekonomicznej w Tarnowie” 2021, nr 51(3), s. 31-33.

9 Por. art. 9 ustawy z dnia 13 listopada 2003 r. o dochodach jednostek samorządu terytorialnego (tekst jedn. Dz.U. z 2021 poz.1672 ze zm.). 
podatku dochodowego od osób prawnych dla danego województwa. Dzięki nowym rozwiązaniom j.s.t. uzyskałyby gwarancję dochodów w każdym następnym roku w wysokości nie niższej niż w roku ubiegłym, co pozwoliłoby na poprawę stabilności finansowej na szczeblu województw, bez uszczerbku dla efektywności wpływów uzyskiwanych z danego źródła ${ }^{10}$.

Konkludując, można wskazać, że dochody poszczególnych j.s.t. stanowiące udział w podatku dochodowym od osób fizycznych są zobrazowaniem sytuacji gospodarczej kraju, a udziały w podatku dochodowym od osób prawnych wyrażają zmiany na rynku lokalnym. Z kolei dochody z podatku od nieruchomości zmniejszyły się na skutek własnych działań samorządów, wspierających lokalną gospodarkę ${ }^{11}$.

\section{Państwowe inicjatywy i projekty finansowego wsparcia jednostek samorządu terytorialnego}

Krajowa polityka gospodarcza przyjęta na rok 2021 prognozuje brak pogorszenia dochodów j.s.t., dlatego podjęto działania mające na celu uzupełnienie uszczuplonych dochodów samorządowych. Jedną z inicjatyw było utworzenie Funduszu Inwestycji Samorządowych przeznaczonego dla gmin (w tym miast na prawach powiatu) i powiatów wyłącznie na inwestycje. Dotacja wraz z odsetkami mogła zostać przekazana przez j.s.t. dowolnie, jednak wyłącznie na wydatki majątkowe. Nie został określony termin wykorzystania dotacji. Sposób obliczania kwoty wsparcia uzależniony był od wysokości planowanych na rok 2020 wydatków majątkowych z uwzględnieniem wysokości dochodów podatkowych powiększonych o subwencję oraz pomniejszonych o wpłatę na ,janosikowe”. Odniesiono je do analogicznie obliczonych gminnych i powiatowych dochodów

10 J. Wantoch-Rekowski, M. Cilak, The share of corporate income tax as revenue of a provincial self-government and the effects of the COVID-19 pandemic, "Ekonomia i Prawo. Economics and Law” 2021, nr 20(2), https://doi.org/10.12775/EiP.2021.027 (dostęp: 18.11.2021 r.), s. 446-448.

11 B. Krawczyk, Pandemia uderza w budżety samorzq̨dów, „Przegląd Komunalny” 2021, nr 1, s. 5-7. 
podatkowych w przeliczeniu na mieszkańca kraju (osobno dla powiatów, dla gmin i miast łącznie, mimo że te ostatnie uzyskują dochody zarówno powiatowe, jak i gminne) ${ }^{12}$. Dalsze transze środków z Funduszu Inicjatyw Samorządowych zostaną przekazywane na realizacje konkretnych inwestycji czy projektów, poddawane ocenie na podstawie kryteriów zawartych w uchwale powołującej, bez względu na kryterium pogorszenia sytuacji finansowej w wyniku działania COVID-19. W tej części nie określono terminu wykorzystania środków, a przy niższych niż planowane kosztach inwestycji nie ma obowiązku zwrotu niewykorzystanej części dotacji (z obligatoryjnym przeznaczeniem jej na wydatki majątkowe).

Wprowadzając zmiany wspierające j.s.t. w wymiarze finansowym, przyjęte zostały rozwiązania pomagające w łatwiejszy sposób zarządzać finansami w czasie pandemii i trwającego zastoju gospodarczego. Wzmocniono kompetencje zarządów j.s.t. oraz wójtów, burmistrzów, prezydentów miast poprzez zezwolenie do samodzielnego zarządzania finansami jednostki bez konieczności odwoływania się do organów stanowiących ${ }^{13}$. Zgodnie z określoną w art. 242 ustawy o finansach publicznych regułą wydatkową operacyjna cześć budżetu j.s.t. powinna opierać się na zasadzie równowagi, w której wydatki bieżące nie powinny przewyższać dochodów bieżących, a deficyt może występować, jeśli zostanie pokryty środkami pochodzącymi z nadwyżki z lat ubiegłych i do wysokości tych środków. Zgodnie z treścią nowelizacji specustawy z 31 marca 2020 r. spod działania reguły wydatkowej wyłączone zostają wydatki bieżące na cele związane z przeciwdziałanie pandemii COVID-19 ${ }^{14}$.

12 P. Swianiewicz, J. Łukomska, Finanse samorządu terytorialnego $w$ dobie pandemii, Warszawa 2020, Fundacja im. Stefana Batorego, https://www.batory.org.pl/wpcontent/uploads/2020/11/Finanse-samorzadu-w-dobie-pandemii.pdf, s.3-5, (dostęp: 10.11.2021 r.).

13 Rozwiązanie to miało jednak charakter epizodyczny, krótkoterminowy wprowadzony nowelizacją specustawy z 19 czerwca 2020 roku.

14 P. Swianiewicz, J. Łukomska, Ewolucja sytuacji finansowej samorzq̨ów terytorialnych w Polsce po 2014 roku, Warszawa 2020, Fundacja im. Stefana Batorego, https://www.batory.org.pl/wp-content/uploads/2020/05/Ewolucja-sytuacji-finansowejsamorzadow_final.pdf, s. 10-13, (dostęp: 10.11.2021 r.). 
Dopuszczony został deficyt operacyjny w kwocie równej ubytkom dochodów będących następstwem pandemii w zakresie podatku dochodowego od osób fizycznych, podatku dochodowego od osób prawnych, a przypadku gmin dodatkowo w zakresie podatku od nieruchomości, rolnego, leśnego, od środków transportowych, od czynności cywilnoprawnych, podatku dochodowego od osób fizycznych w formie karty podatkowej, wpływy z opłat skarbowej i eksploatacyjnej. Dodatkowo uwzględniono wpływy z opłaty miejscowej i uzdrowiskowej. Ubytek dochodów obliczany jest w stosunku do planowanych dochodów z tych źródeł zgodnie z tym, jaki plan został uwzględniony w sprawozdaniu budżetowym za pierwszy kwartał danego roku. W przypadku zmiany budżetu w trakcie roku można planować deficyt operacyjny do kwoty różnicy między łącznymi dochodami podatkowymi według planu z 31 marca a łącznymi dochodami podatkowymi według nowego, zmienionego planu. Za cały rok kwota wykonanego deficytu operacyjnego może być równa różnicy między planowanymi na 31 marca łącznymi dochodami podatkowymi a wykonaną łączną kwotą tych dochodów. Przepis dotyczy nadwyżki wydatków bieżących nad dochodami bieżącymi, która przekracza to, co dopuszczalne na podstawie innych przepisów, czyli ponad tę jej część, którą można sfinansować z nadwyżki budżetowej z ubiegłych lat oraz wolnych środków, oraz tę część, która powstała w wyniku poniesienia wydatków na przeciwdziałanie pandemii.

Ważnym instrumentem pozwalającym kontrolować poziom zadłużenia jest limit wysokości spłaty zobowiązań w poszczególnych latach budżetowych ${ }^{15}$. Na podstawie danych historycznych ustalana jest wysokość dochodów, jaką dana j.s.t. może przeznaczyć na spłatę zadłużenia oraz pokrycie kosztów obsługi długu, okręcając limit rocznej spłaty poprzez odniesienie tak obliczonego wskaźnika do dochodów prognozowanych dla przyszłych lat. Zmieniono sposób obliczania nadwyżki operacyjnej, zgodnie z którym będzie ona obliczana z wyłączeniem wydatków na obsługę długu, poczynając od roku 2020. Zniesieniu obciążenia nadwyżki operacyjnej obsługi długu będzie towarzyszyło równoległe zniesienie jej

15 Por. art. 243 ustawy z dnia 27 sierpnia 2009 r. o finansach publicznych (tekst jedn. Dz.U. z 2021 poz. 305 ze zm.), dalej: ustawa o finansach publicznych lub u.f.p. 
powiększania, na użytek obliczania zdolności kredytowej, o dochody ze sprzedaży majątku, co spowoduje bardziej liberalny niż dotychczas sposób oceny zdolności kredytowej j.s.t. ${ }^{16}$

Główne cele zmian w zakresie deficytu operacyjnego oraz zaciągania zobowiązań dotyczą ograniczenia limitów prawnych dla wydatków mających za przedmiot zwalczanie pandemii COVID-19 i jej skutków, które mogą być dokonywane nawet w sytuacji stwierdzenia złej sytuacji finansowej danej j.s.t. poprzez finansowanie z dochodów majątkowych lub z przekroczeniem limitu zobowiązań. Istotne jest także stałe dokonywanie przez j.s.t. wydatków bieżących, pomimo spadku dochodów, dzięki zwiększeniu deficytu operacyjnego do wysokości ubytku w dochodach oraz wyłączenie spod rygorów art. 243 ustawy z dnia 27 sierpnia 2009 r. o finansach publicznych zaciąganego w roku 2020 długu do tej samej wysokości, zapewnienie możliwości kontynuacji inwestycji w przypadku spadku dochodów.

Trudna sytuacja finansowa j.s.t. ma charakter przejściowy i prognozowana jest poprawa kondycji finansów samorządowych w kolejnych latach, która usprawiedliwia zastosowanie zliberalizowanych reguł. Zmiany przepisów w zakresie sytuacji finansowej samorządów, która ma nadzwyczajny charakter podyktowany okolicznościami, nie będzie uwzględniane przy całościowej ocenie kondycji finansów j.s.t. w kolejnych latach.

\section{Wnioski końcowe}

Konkludując powyższe rozważania dotyczące sytuacji finansowej jednostek samorządu terytorialnego w obliczu trwającej pandemii COVID-19 i jej skutków, należy stwierdzić, że nie są widoczne drastyczne skutki pogorszenia sytuacji, jednak aktualne dane nie pozwalają też na nadmierny optymizm. Samorządy zostały postawione przed wyzwaniem na płaszczyźnie zarówno organizacyjnej, jak i finansowej, co wymusiło komplek-

16 Por. art. 243 [w:] J. Salachna, K. Stelmaszczyk, M. Tyniewicki, Komentarz do ustawy o finansach publicznych dla jednostek samorzq̨du terytorialnego, Gdańsk 2019, s. 846-852. 
sowe, jednoczesne działania. Zagrożenie wirusem SARS-CoV-2 wpłynęło na sytuację społeczną, gospodarczą, działania administracji publicznej na każdym szczeblu. Podsumowując podjęte działania i wdrożone instrumenty, należy stwierdzić, że wzrost dochodów j.s.t. jest niższy niż zakładano w zestawieniu z rokiem 2020. Można wskazać jako wniosek de lege lata, że rosnące wydatki podyktowane przeciwdziałaniem skutkom pandemii spowodowały zmniejszenie nadwyżki bieżącej j.s.t., jednak bez zagrożenia dla płynności finansowej j.s.t. Samorządy inwestują środki publiczne, co stanowi jedno ze skutecznych narzędzi $\mathrm{w}$ walce z zapaścią gospodarczą. Pandemia wpłynęła na spadek liczby planowanych oraz zrealizowanych inwestycji i projektów ${ }^{17}$. Taki zastój wpłynie negatywnie nie tylko na gospodarkę, ale także będzie widoczny dla społeczności lokalnych. Wiele projektów zostało znacznie przesuniętych w czasie, z innych samorządy zrezygnowały. Ważne, że j.s.t. utrzymały nadwyżkę bieżącą, która posłużyła realizacji większości z zaplanowanych dochodów oraz realizowania zadań publicznych. Jako postulat de lege ferenda należy wskazać konieczność wnikliwej i systematycznej analizy wpływu pandemii COVID-19 na j.s.t. przy uwzględnieniu różnych obszarów zadań realizowanych przez gminy, powiaty i województwa. Kluczowe, aby monitorować długoterminowo skutki pandemii oraz metody, które mogą przyczynić się do przeciwdziałania jej skutkom. Ważnym postulatem zmian prawodawczych, które pozwoliłyby na uzupełnienie niedoborów wpływów z podatku dochodowego od osób prawnych dla danego województwa, byłoby wprowadzenie gwarancji dochodów w każdym następnym roku w wysokości nie niższej niż w roku ubiegłym, co pozwoliłoby na poprawę stabilności finansowej na szczeblu województw, bez uszczerbku dla efektywności wpływów uzyskiwanych z danego źródła.

17 M. Gołaszewski, Wpływ załamania gospodarczego zwiqzanego z COVID-19 na finanse, sytuację zadłużeniowq i płynnościowq JST, http://www.kongresadministracji.pl/wpcontent/uploads/2020/06/Konsekwencje-zatrzymania-gospodarki-dla-finansow-jstKZAS-06.2020-3.pdf, s. 24-30, (dostęp: 13.11.2021 r.). 


\section{Bibliografia:}

Gołaszewski M., Finanse samorzq̨dowe jeszcze bardziej zagrożone, „Wspólnota” 2020, nr 4, s. 22-26.

Gołaszewski M., Wpływ załamania gospodarczego zwiqzanego z COVID-19 na finanse, sytuację zadłużeniowq i płynnościowq JST, http://www.kongresadm inistracji.pl/wp-content/uploads/2020/06/Konsekwencje-zatrzymaniagospodarki-dla-finansow-jst-KZAS-06.2020-3.pdf, (dostęp: 13.11.2021 r.).

Kostyk-Siekierska K., Wpływ pandemii COVID-19 na sytuację finansowq i funkcjonowanie jednostek samorzqdu terytorialnego, „Zeszyty Naukowe Małopolskiej Wyższej Szkoły Ekonomicznej w Tarnowie” 2021, 51 (3), s. 29-45.

Krawczyk B., Pandemia uderza w budżety samorzq̨dów. „Przegląd Komunalny” 2021, nr 1, s. 1-12.

Nelicki A., Wpływ ustawodawstwa okresu pandemii COVID-19 na finanse jednostek samorzq̨u terytorialnego, Warszawa 2020, Fundacja im. Stefana Batorego, https://www.batory.org.pl/wp-content/uploads/2020/11/Wpływ-ustawo dawstwa-okresu-pandemii-COVID-19-na-finanse-JST.pdf, (dostęp: 10.11.2021).

Salachna J., Stelmaszczyk K., Tyniewicki M., Komentarz do ustawy o finansach publicznych dla jednostek samorzq̨du terytorialnego, ODDK, Gdańsk 2019.

Swianiewicz, P., Łukomska, J., Ewolucja sytuacji finansowej samorzq̨ów terytorialnych w Polsce po 2014 roku Warszawa 2020, Fundacja im. Stefana Batorego, https://www.batory.org.pl/wp-content/uploads/2020/05/Ewolucjasytuacji-finansowej-samorzadow_final.pdf, (dostęp: 10.11.2021 r.).

Swianiewicz, P., Łukomska, J., Finanse samorzqdu terytorialnego $w$ dobie pandemii, Warszawa 2020, Fundacja im. Stefana Batorego, https://www.batory.org.pl/wp-content/uploads/2020/11/Finanse-samorzaduw-dobie-pandemii.pdf, (dostęp: 10.11.2021 r.).

Wantoch-Rekowski J., Cilak M., The share of corporate income tax as revenue of a provincial self-government and the effects of the COVID-19 pandemic, “Ekonomia i Prawo. Economics and Law” 2021, 20(2), https://doi.org/ 10.12775/EiP.2021.027 (dostęp: 18.11.2021 r.), s. 439-456. 